\title{
Людмила Рябець
}

Інститут української мови НАН України

Київ

ORCID: 0000-0003-4829-715X; e-mail: riabetslv@ukr.net

\section{Materiały do osiągnięć leksykografii słowiańskiej}

JĘZYK: українська мова;

TYTUŁ: Мовний портрет села Тюдів; т. I: $A-M$;

AUTOR / AUTORZY: Марія Голянич; науковий редактор Павло Гриценко;

MIEJSCE i ROK WYDANIA: Івано-Франківськ, 2018;

ISBN: 978-966-668-478-6;

TYP i UKŁAD HASEŁ: алфавітний порядок словникових статей;

BUDOWA ARTYKUŁU HASŁOWEGO: словникова стаття містить реєстрове слово, пояснення його значення, ілюстрацію - фрагмент говіркового мовлення, у якому наявне відповідне слово; у словнику використано різні типи ремарок; UWAGI: праця має структуру словника однієї говірки; говірка села Тюдів Косівського району Івано-Франківської області не потрапила до мереж відомих лінгвістичних атласів, не була представлена в жодному 3 діалектних словників чи монографічних описів, тому цей словник суттєво удокладнює вже відомі свідчення про гуцульський діалект; для авторки ця говірка $є$ рідною, тому тут відтворено мовлення іï батьків, близьких і далеких родичів, односельців кількох поколінь; формат словника дозволив використати текстові ілюстрації різного обсягу, подати розлогі наративи, широко презентувати фразеологію; хоча текст словника не обтяжений деталізованою фонетичною транскрипцією, проте відтворює виразний індивідуальний звуковий портрет говірки; подано широку сполучуваність лексем (особливо дієслів); авторці вдалося зафіксувати й відобразити різноманітні деталі щоденного життя тюдівської спільноти, неповторну локальну культуру гуцульського краю; у додатках уміщено світлини різних років, підписані розлогими транскрибованими текстами. 
JEZYK: українська мова;

TYTUŁ: Словник украӥнських говірок Бузько-Інгульського межиріччя;

AUTOR / AUTORZY: Укладачі: Л.С. Спанатій, А.П. Супрун, М.Ф. Тимченко, В.П. Токар; за загальною редакцією Л.С. Спанатій; науковий редактор П.Ю. Гриценко;

MIEJSCE і ROK WYDANIA: Миколаїв, 2018;

ISBN: 978-617-534-502-3;

LICZBA HASEL: близько 20000 діалектизмів;

TYP i UKŁAD HASEŁ: алфавітний порядок словникових статей;

BUDOWA ARTYKUŁU HASLOWEGO: словникова стаття містить: реєстрове слово із вказівкою на граматичні особливості та стилістичні риси слова; значення реєстрового слова, що здебільшого розкривається описово наявним у літературній мові відповідником-синонімом, рідше - комбінованим словом, іноді подається детальний опис предмета, явища, обряду тощо; ілюстративний матеріал, дібраний iз записів живого мовлення жителів сіл Миколаївської області; вказівку на локалізацію словоформ, яку передано цифровими позначеннями, уживаними в довіднику "Миколаївська область. Адміністративно-територіальний поділ" (Одеса, 1978);

UWAGI: словник укладено за розробленою кафедрою української мови Миколаївського педагогічного інституту програмою для збирання говірок (орієнтиром для укладачів була «Програма для збирання матеріалів до Лексичного атласу української мови» Й.О. Дзендзелівського), що охоплює всі сфери життя і діяльності людей; збирання лексичного матеріалу тривало понад 40 років; формування українських степових говірок Бузько-Інгульського межиріччя, яке бере початок із XVIII століття, тісно пов'язане $з$ історією заселення краю; основу цих говірок складають середньонаддніпрянські говірки із вкрапленням говірок північного й південно-західного наріч; у різний час ці говірки зазнали впливу білоруських, російських, болгарських, частково - німецьких, польських, чеських, грецьких, сербських та інших говірок. 